\section{Analisis Yuridis Mengenai Strategi Dosen Terkait Dengan Mutu Pembelajaran Di Perguruan Tinggi Masa Era New Normal}

Oleh:

\author{
1.Halimatul Maryani \\ halimatul.maryani@umnaw.ac.id
}

\section{Abdul Halim (Universitas Al-Washliyah) Email:abdulhalim93@gmail.com}

\section{Abstract}

The scope of education is the parties that are involved in the sphere of education such as proteges/students/college students, the basic and the purpose of education itself, educators, educational materials, educational methods, educational evaluation, educational tools and the surrounding environment within the scope of education. Education is also one of the most important parts of human life that has provisions that aim to help the improvement of living standard and life for themselves and for the country. If referring to the Article 31 (amendment) paragraph (1) of the 1945 Constitution of the Republic of Indonesia which states that "Every citizen has the right to education, of course education is meant in principle, learning what we know is based on face to face in the class. to transfer the knowledge to their students (students / college students). This has now turned into virtual, distance learning, due to various constraints of limited facilities and infrastructure, the ability to absorb the technology, on the other hand, the unstable condition of the spread of covid-19 has certainly become a dilemma for several universities, including the university of Muslim Nusantara Al Washliyah in implementing learning whether it's pure online use organized with Distance Learning (PJJ) -virtual and other types of virtual.

Keywords : Strategy, the Quality of Learning,New Normal

\section{Abstrak}

Ruang lingkup pendidikan merupakan pihak-pihak yang terlibat dalam lingkup pendidikan seperti, anak didik/siswa/mahasiswa, dasar dab tujuan pendidikan itu sendiri, pendidiknya, materi pendidikan, metode pendidikan, evaluasi pendidikan, alat-alat pendidikan dan lingkungan sekitarnya dalam ruang lingkup pendidikan.Pendidikan jga meruapakan salah satu bagian terpenting dalam kehidupan manusia yang memiliki bekal yang bertujuan untuk membantu peningkatan tarap hidup dan kehidupannya untuk diri maupun untuk negara. Jika merujuk pada Pasal 31 (amandemen) ayat (1) Undang-Undang Dasar Negara republik Indonesia tahun 1945 yang menyatakan bahwa "Setiap warga negara berhak mendapatkan pendidikan, tentunya pendidikan dimaksud pada prinsipnya pembelajarannya yang kita kenal berdasarkan tatap muka di kelas. untuk melakukan transfer ilmu pengetahuan (knowledge) kepada peserta didiknya (siswa/mahasiswa). Hal ini kini berubah menjadi virtual, pembelajaran jarak jauh, karena berbagai kendala keterbatasan sarana dan prasarana, kemampuan dalam menyerap tehnologi, hari ini sebaliknya belum stabilnya kondisi penyebaran covid-19 tentunya menjadi dilema beberapa perguruan tinggi, termasuk Universitas Muslim Nusantara Al Washliyah dalam penerapan pembelajaran apakan sudah murni menggunakan daring yang diselenggarakan dengan Pembelajaran Jarak Jauh (PJJ)-virtual dan jenis virtual lainnya.

Kata Kunci: Strategi, Mutu Pembelajaran, New Normal.

\section{Pendahuluan}

\section{A. Latar Belakang}

Ruang lingkup pendidikan merupakan pihak-pihak yang terlibat dalam lingkup pendidikan seperti. Anak didik/siswa/mahasiswa, dasar dan tujuan pendidikan itu sendiri, pendidiknya, materi pendidikan, metode pendidikan, evaluasi pendidikan, alat-alat pendidikan dan lingkungan sekitarnya dalam ruang lingkup pendidikan. Pendidikan jga meruapakan salah satu bagian 
Media Komunikasi dan Informasi Hukum dan Masyarakat

terpenting dalam kehidupan manusia yang memiliki bekal yang bertujuan untuk membantu peningkatan tarap hidup dan kehidupannya untuk diri maupun untuk negara. Maka oleh sebab itu pendidikan itu sangat perlu di manan pendidikan ini adalah suatu sikap yang terencana untuk mewujudkan suasana belajar dan proses pembelajaran yang membuat siswa/mahasiswa (peserta didik) aktif dan dapat mengembangkan potensi dirinya untuk menambahkan kecerdasan, akhlak mulia serta kemapuan dan keterampilan yang diperlukan untuk diri pribadi, keluarga, masyakarat, bangsa dan negara, khususnya NKRI.

Jika merujuk pada Pasal 31 (amandemen) ayat (1) Undang-Undang Dasar Negara Republik Indonesia tahun 1945 yang menyatakan bahwa "Setiap warga negara berhak mendapatkan pendidikan, dan ayat (2) menyatakan bahwa setiap warga negara wajib mengikuti pendidikan dasar dan pemerintah yang membiayainya, ayat (3) bahwa pemerintah mengushakan dan menyelenggarakan satu sistem pendidikan nasional yang meningkatkan keimanan dan ketaqwaan, serta akhlak mulia dalam rangka mencerdaskan kehidupan bangsa (diatur dengan undang-undang). Melihat hal ini maka pendidikan ini sangat penting untuk anak bangsa, khususnya bangsa Indonesia yang bersifat formal dan non formal yang pada dasarnya berlangsung dengan tatap muka, di ruang kelas, selama dua semester dalam satu tahun ajaran.

Namun saat ini, dalam kondisi pendidikan kita di Indonesia khususnya di masa new normal selama masa penyessuai new normal muncul beberapa opini tentunya ada yang pro dan ada yang kontra dikalangan semua insan perguruan tinggi termasuk mahasiswa dan khususnya dosen sebagai personil utama yang bertanggung jawab untuk melakukan transfer ilmu pengetahuan (knowledge) karena berbagai kendala keterbatasan sarana dan prasarana, kemampuan dalam menyerap tehnologi, belum stabilnya kondisi penyebaran covid-19 tentunya menjadi dilema beberapa perguruan tinggi, termasuk Universitas Muslim Nusantara Al Washliyah dalam penerapan pembelajaran apakan sudah murni menggunakan daring (dalam jaringan) yang diselenggarakan dengan Pembelajaran Jarak Jauh (PJJ)-virtual dan jenis virtual lainnya.

Berdasarkan latar belakang ini, maka penelitian ini berjudul "Strategi Dosen Terkait Dengan Mutu Pembelajaran di Perguruan Tinggi Masa Era New Normal.

\section{B. Rumusan Masalah}

Berdasarkan latar belakang yang telah diuraikan diatas, maka rumusan masalah yang dapat dikaji dalam penelitian ini adalah tentang bagaimana model kesiapan dosen dalam meningkatkan mutu pendidikan Indonesia di era new normal?

\section{Metode Penelitian}

Penelitian ini bersifat deskriptif analitis, yaitu suatu metode yang digunakan untuk menggambarkan dan menganalisis mengenai situasi atau kejadian dan menerangkan hubungan antara kejadian tersebut dengan masalah yang akan diteliti.

Jenis penelitian ini adalah adalah penelitian yuridis empiris. Penelitian yuridis empiris adalah pendekatan permasalahan mengenai hal-hal yang bersifat yuridis dan kenyataan yang ada mengenai hal-hal yang bersifat yuridis. Penelitian hukum empiris atau penelitian sosiologis yaitu penelitian hukum yang menggunakan data primer. Menurut pendekatan empiris pengetahuan didasarkan 
Media Komunikasi dan Informasi Hukum dan Masyarakat

atas fakta-fakta yang diperoleh dari hasil penelitian dan observasi ${ }^{1}$.

\section{Hasil dan Penelitian Tentang Model Kesiapan Dosen Dalam Meningkatkan Mutu Pendidikan Indonesia Di Era New Normal.}

Dalam Undang-Undang Republik Indonesia No. 20 Tahun 2003 tentang Sistem Pendidikan Nasional secara Umum pendidikan nasional berdasarkan pada Pancasila dan Undang-Undang Dasar Tahun 1945. Selanjutnya dalam Pasal 3 menyatakan bahwa pendidikan nasional berfungsi untuk mengembangkan kemampuan dan membentuk watak serta peradaban bangsa yang bermartabat dalam rangka mencerdaskan kehidupan bangsa, bertujuan untuk mengembangkan potensi peserta didik agar menjadi manusia yang beriman dan bertaqwa kepada Tuhan Yang Maha Esa, berakhlak mulia, sehat, berilmu, cakap, kreatif, mandiri dan menjadi warga Negara yang demokratis serta bertanggung jawab.

Pendidikan adalah proses
pengembangan potensi individu menjadi potensi nyata yang diperlukan untuk menjalani kehidupan yang bermartabat, baik sebagai pribadi, anggota masyarakat, warga Negara dan warga masyarakat dunia. Proses pengembangan potensi tersebut terjadi dalam lingkungan keluarga, sekolah, dunia kerja, dan masyarakat. $^{2}$ Semua lingkungan tersebut mempunyai perannya masing-masing, Sedangkan Perguruan Tinggi adalah merupakan sebuah lembaga pendidikan untuk

${ }^{1}$ Ronny Hanitijo Soemitro, Metodologi Penelitian Hukum dan Jurimetri, Ghalia Indonesia, Jakarta, 2009, hal. 10

${ }^{2}$ Djam'an Satori, Sistem Penjaminan dan Peningkatan Mutu Pendidikan, disampaikan pada pidato orasi ilmiah dalam rangka wisuda pasca sarjana UMN AlWashliyah Medan tanggal 17 Maret 2012. mencetak para sarjana, cendikiawan dan akademisi, ${ }^{3}$ sampai memperoleh gelar sarjana.

$$
\text { Pendidikan Indonesia adalah }
$$

pendidikan yang ada di di Indonesia, yaitu bahwa pendidikan di Indonesia dilaksanakan dan dibagi dalam beberapa jenjang, dan jenjang pendidikan tersebut dibagi berdasarkan tingkatan usia dan kemampuan peserta didik dimana masing-masing jenjang pendidikan memiliki rentang usia dan lama pendidikan yang berbeda-beda sesuai dengan kebutuhannya masing-masing. Jenjang pendidikan adalah tahapan pendidikan yang ditetapkan berdasarkan tingkat perkembangan peserta didik, tujuan yang akan dicapai dan kemampuan yang dikembangkan, ${ }^{4}$ yaitu pendidikan dasar, pendidikan menengah dan pendidikan tinggi.

Sejalan dengan kondisi baru saat ini "new normal", maka siapapun yang mengelola tempat umum, tempat kerja, sekolah, yayasan, tempat ibadah, termasuk pendidikan tinggi harus melakukan serta melaksanakan aspek protokol yang berkaitan dengan masa pandemic covid-19 yang menjadi control terhadap kedisiplinan seluruh masyarakat. Nah, untuk merealisasikan kondisi masa pandemic covid-19 ini pemerintah telah menggandeng seluruh pihak yang terkait, termasuk tokoh masyarakat, para ahli/pakar untuk merumuskan protocol, standar operasional prosedur untuk memastikan para masyarakat dapat beraktifitas kembali dan tetap aman serta terhindar dari covid-19. Sehubungan dengan itu pula, maka penelitian ini berjudul "Strategi Dosen Terkait Dengan Mutu Pembelajaran di Perguruan Tinggi Era New Normal, khususnya di lingkungan Universitas Muslim Nusantara al washliyah

${ }^{3} \mathrm{Http}: / /$ humas.narotama.ac.id. Pentingnya startegi marketing bagi perguruan Tinggi, diakses pada tanggal 20 Mei 2014.

${ }^{4}$ Lihat Undang-Undang No. 20 Tahun 2003 tentang sistem pendidikan nasional tepatnya pasal 1 ayat 8 . 
Media Komunikasi dan Informasi Hukum dan Masyarakat

(UMN Al Washliyah). New normal saat ini menjadi model kehidupan baru yang diadaptasi oleh hampir seluruh negara yang menjadi referansi untuk suatu perubahan prilaku dalam masyarakat terlebih dalam prilaku di masa pandemic covic-19, salah satunya adalah sektor pendidikan.

Tatanan baru untuk adaptasi dengan covid-19, dimana kebiasaan serta perilaku yang baru berbasis pada adaptasi untuk membudayakan prilaku yang hidup bersih, sehat sesuai dengan protocol kesehatan dari pemerintah dan ini disebut dengan "new normal', misalnya dunia pendidikan kita merupakan salah satu bidang yang berdampak oleh pandemic covid-19 yang masuk ke negara Indonesia sejak bulan Maret 2020. Nah menyikapi hal ini maka menteri pendidikan dan kebudayaan telah menerbitkan Surat Edaran No. 4 tahun 2020 yang isinya ada beberapa kebijakan yang diambil selama pandemic covid19 antara lain ada kebijakan dibatalkannya Ujian Nasional 2020 dimana pembelajarannya awalnya menggunakan tatap muka, menjadi pembelajaran jarak jauh (PJJ) atau belajar dari rumah (BDR).

Sebagai langkah adaptasi di masa pandemic covid-19 ini dalam hal melakukan pembelajaran di perguruan tinggi berbasis adaptasi untuk memberdayakan prilaku hidup bersih dan sehat, inilah yang disebut dengan "new normal"5. Cara yang dilakukan saat ini dalam melakukan semua aktivitas di masa pandemic covid-19 adalah dengan rutin cuci tangan pakai sabaun, pakai masker saat keluar rumah, jaga jarak aman dan menghindari kerumuanan, serta lainnya. Semua pihak berharap agar semua kebiasaan baru ini "new

${ }^{5}$ Arti new normal Indonesia:tatanan Baru beradaptasi dengan Covid-19, 2020 dalam www.https://, diakses pada hari Senin, 20 Oktober 2020. normal' harus menjadi kesadaran kolektif agar dapat berjalan dengan baik.

Merujuk kepada motto" Ing Ngarso Sung Tulodo, Ing Madya Mangun Karso, dan Tut Wuri Handayani" oleh Ki Hajar Dewantara, 1889, yang dikenal dengan tokoh pendidikan yang bermakna di depan memberi teladan, di tengah membangun kemauan, dan di belakang memberi dorongan dan pengaruh, ini memberi makna bahwa pendidikan itu sangat penting.

Dalam melirik reformasi pembelajaran yang sedang berkembang di Indonesia khususnya di masa pamdemi covid-19 (new normal) saat ini, para dosen di perguruan tinggi tentunya dihadapkan dengan banyaknya pilihan model penyesuaian pembelajaran di kelas dengan literatur-literatur baru, khususnya di era new normal, yang harus dipahami adalah proses dalam pelaksanaan pembelajaran. ${ }^{6}$

Model-model pilihan tersebut, tidak akan pernah kaku jika seorang dosen itu tetap menguasai konsep dan teori dasar pembelajaran yang merujuk kepada konsep dan teori proses pembelajaran, maka pada dasarnya dosen harus dapat dengan kreatif mengembangkan model pembelajaran ini sesuai dengan kondisi nyata (riil situation) saat ini (new norma), sehingga pada gilirannya pasti muncul model dan strategi lainnya yang dapat mengkombain dan tentunya dapat memperkaya khazanah model pembelajaran itu sendiri.

Dalam pasal 6 UU No. 14 Tahun 2005 tentang Guru dan Dosen dijelaskan bahwa kedudukan dosen sebagai tenaga propesional bertujuan untuk melaksanakan sistem pendidikan nasional dan mewujudkan tujuan pendidikan nasional, yaitu

${ }^{6}$ Istilah pembelajaran juga disebut dengan "instructional" yakni dengan makna yang saat ini adalah termasuk peran aktif dari pengajar untuk membelajarkan kepada siswa/mahasiswa/anak didiknya, kalau pengertaian pembelajaran dalam konsep awal adalah pengajaran (teaching) den identik dengan makna penyampaian materi. 
Media Komunikasi dan Informasi Hukum dan Masyarakat

berkembangnya potensi peserta didik agar menjadi manusia yang beriman dan bertaqwa kepada Tuhan Yang Maha Esa, berakhlak mulia, sehat, berilmu, cakap, kreatif, mandiri serta menjadi warga Negara yang demokratis dan bertanggung jawab.

Berkaitan dengan hal tersebut, dosen berarti pendidik professional dan ilmuan dengan tugas utamanya adalah menstranformasikan, mengembangkan dan menyebarluaskan ilmu pengetahuan yang dimiliki sesuai dengan bidangnya seperti wawasan, teknologi, seni melalui pendidikan, penelitian dan pengabdian masyarakat sebagai Tri Dharma Perguruan Tinggi yang telah memiliki Nomor Induk Dosen Nasional yang disingkat dengan (NIDN) dan jabatan fungsional (jafung), seperti Asisten Ahli, Lektor, Lektor Kepala maupun Guru Besar. Untuk itu setiap orang yang menjadi dosen tentunya mempunyai karakteristik sesuai dengan karakternya masing-masing dengan tetap mengarah kepada sistem pendidikan di Indonesia.

Rekayasa model pembelajaran dan strateginya pun dapat di desain oleh dosen itu sendiri dengan sedemikan rupa dan tetap merujuk kepada konsep pembelajaran itu sendiri. Namun yang perlu harus diingat adalah bahwa kemampuan siswa/mahasiswa tersebut tidak sama, misalnya kemampuannya benarbenar mampu, kemampuannya ada yang sedang, dan ada yang kurang, artinya si mahasiswa itu memliki kekurangan dan kelebihan masing-masing, oleh karena itu memerlukan strategi. Sebagai dasar awal dapat dipahami konsep dan sudau pandang pembelajaran berikut ini dalam gambar.

Tabel.1. Konsep Sudut Pandang Pembelajaran

\begin{tabular}{|c|c|}
\hline Konsep & Sudut Pandang \\
\hline Learning & Peserta \\
& didik/mahasiswa/pelaj \\
& ar \\
\hline
\end{tabular}

\begin{tabular}{|c|c|}
\hline Teaching & didik/pengajar/fasilitator \\
\hline Instruction & $\begin{array}{c}\text { eraksi antara pengajar } \\
\text { dan pesertanya } \\
\text { dengan media sumber } \\
\text { pembelajaran }\end{array}$ \\
\hline
\end{tabular}

Catatan: sumber dikutip dari buku Abdul Mujib dalam strategi pembelajaran, 2017, diolah dan dikembangkan oleh penulis.

Berdasarkan ilustrasi tabel tersebut, maka pembelajaran itu merupakan kegiatan terencana yang mengkondisikan seseorang itu agar bisa belajar dengan baik sesuai dengan tujuan pembelajaran, di mana pembelajaran itu akan bermuara pada dua kegiatan pokok yakni orang melakukan tindakan perubahan tingkah laku melalui kegiatan belajar dan bagaimana orang melakukan tindakan penyampaian ilmu melalui kegiatan mengajar. ${ }^{7}$ Disamping itu juga dalam pembelajaran sebaiknya diperhatikan beberapa hal, diantaranya bahwa pelaksanaan pembelajaran itu dilaksaanakan dengan pengalaman dan sesuai dengan lingkungan, isi pembelajaran tersebut juga harus di desain sedemikian rupa sesuai dengan karakteristik mahasiswa.anak didiknya, ${ }^{8}$ media dan sumber bahan belajar disediakan dengan baik, serta ada ukuran penilaiannya terhadap masingmasing mahasiswa/anak didik itu.

Hal ini juga sejalan dengan konsep pembalajaran di masa pandemic covid-19 atau new normal, dengan rincian sebagai berikut dalam gambar ini.

Gambar.1. Konsep Pembelajaran Online

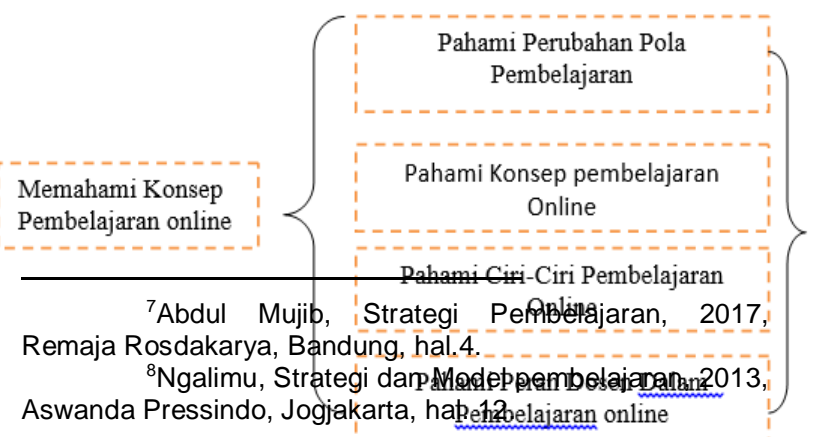


Pada prinsipnya dalam meningkatkan mutu pembelajaran khususnya pembelajaran di kelas, tentunya dosen memiliki strategi, maksudnya bermakna siasat perang yang direncanakan untuk mendapatkan tujuan yang sudah direncanakan, 9 yang tepat untuk melakukan proses pembelajaran secara rasional dan inovasi. Dosen juga juga harus bisa membuat inovasi dalam hal pembelajaran dengan tujuan luaran dari hasil pembelajarn ini dapat diterapkan dengan baik, diantaranya bahwa dosen harus menggunakan somber belajar internal dan ekternal dengan menggunakan tehnologi dengan peningkatan kompensi abad 21. Bukan itu saja rasional perlunya inovasi pembelajaran untuk memotivasi mahasiswa menjadi pelajar sepanjang hayat dengan pembinaan etika yang baik, serta dapat meningkatkan perkembangan ilmu pengetahuan, tehknologi dan inovasi yang semakin pesat. Nah, untuk meningkatkan mutu pembelajaran tersebut seorang dosen perlu pengembangan kinerja yang baik, sebagai contoh dapat dirincikan dalam gambar skema berikut ini.

Gambar.2. Skema llustrasi Rencana Kerja Dosen

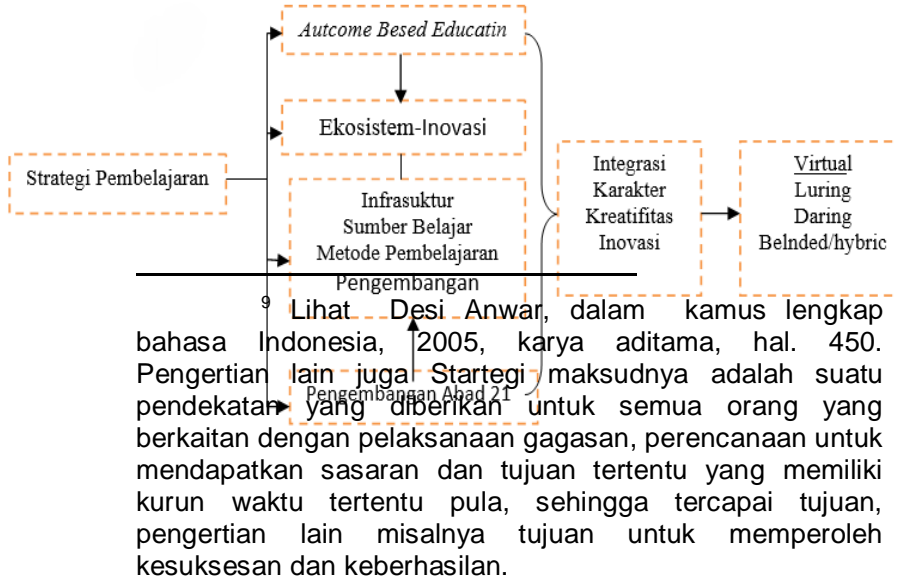

Berdasarkan gambar tersebut, maka dapat dipahami bahwa strategi pembelajaran dalam meningkatkankan mutu pembelajaran dapat dikembangkan oleh dosen yang bersangkutan berdasarkan matakuliah yang diampu dengan menerapkan metode dasar yang dimiliki, seperti dengan memanfaatkan infrastuktur, pengayaan sumber belajar, penerapan model pembelarannya, dan pengembangan proses pembelajarannya yang tetap berhubungan erat dengan pengembangan pengembangan pembelajaran dalam abad 21 . Lalu bagaimana pula hubungan dengan proses pembelajaran di era new normal (pamdemi covid-19) saat ini, tentunya ada pengembangan dan inovasi baru dalam hal proses pembelajaran tersebut.

$$
\text { Pelaksanaan pembelajaran di }
$$

pandemic-19 ini tetap virtual, namun bervariasi seperti daring dengan dua variasi, selanjutnya dengan kombinasi (belnded/hybric), kemudian ada yang luring dengan sistem beri tugas dikumpul pada saat yang ditentukan, selanjutnya juga pelaksanaan pembelajaran saat new normal ini ada juga pelaksanaannya dengan tatap muka dengan terbatas, seperti praktek untuk fakultas hukum ada praktek peradilan semu, seminar, dan meja hijau, terlepas dari itu pula proses pembelajaran yang dilakukan merupakan proses kependidikan yang terencana, terpadu, dan terkoordinasi ${ }^{10}$, serta sistematis dengan standar ukuran evaluasi yang jelas.

\section{Penutup}

${ }^{10}$ Jasa Unggah Muliawan, 45 Model pembelajaran spektakuler, Arruzz Media, Jogjakarta, 2016, hal, 15 
Media Komunikasi dan Informasi Hukum dan Masyarakat

Berdasarkan paparan di atas, maka sebagai penutup kata dalam penelitian ini dapat disimpulkan bahwa startegi pembelajaran yang dilakukan dosen dalam masa pandemic covid19 "new normal' ini tetap daring, dan daringnya dengan bervariasi dan disesuaikan dengan kondisi saat ini, diantaranya adalah virtual atau daring. Pelaksanaan secara online atau daring ada dua variasi, yakni daring dengan ful di mana dosen mengajar dari rumah, daring dengan dosen datang ke kampus. selain itu ada juga pelaksanaan dengan luring, serta tatap muka dengan terbatas, seperti praktek, seminar dan sidang meja hijau.

Selanjutnya, mengenai proses pembelajaran merupakan proses pembelajaran yang terpadu, sistematis dan terencana, terkait dengan masa covid-19 ini memang banyak variasi, model, dan strategi yang lakukan dosen untuk mengajar, nanum tetap merujuk pada konsep dan sudut pandang pembelajaran, seterusnya bervariasi dengan konsep pembelajaran secara online/daring, dengan tetap menguasai materi yang akan disampaikan kepada mahasiswa khususnya di kelas, baik kelas daring maupun kelas yang dilakkan dengan luring.

\section{DAFTAR PUSTAKA}

\section{A. Buku}

Abdul Mujib, Strategi Pembelajaran, Bandung, Remaja Rosdakarya, 2017.

Bambang Sunggono, Metode penelitian hukum (Suatu Pengantar), PT. RajaGrafindo Persada, Jakarta, 2001.

Djam'an Satori, Sistem Penjaminan dan Peningkatan Mutu Pendidikan, disampaikan pada pidato orasi ilmiah dalam rangka wisuda pasca sarjana UMN AI-Washliyah Medan tanggal 17 Maret 2012.

Jasa Unggah Muliawan, 45 Model pembelajaran spektakuler, Arruzz Media, Jogjakarta, 2016.

Johnny Ibrahim, Teori \& Metodologi Penelitian Hukum Normatif, Bayumedia, Malang, 2005.

Peter Mahmud Marjuki, Penelitian Hukum, Kencana, Jakarta, 2005.

\section{B. Peraturan Perundang-Undangan}

Undang-Undang No. 20 Tahun 2003 tentang Sistem Pendidikan Nasional.

UU No. 14 Tahun 2005 Tentang Guru Dosen.

\section{Internet}

Jenjang pendidikan di Indonesia menurut UU Sistem Pendidikan di Indonesia Tahun 2003 http://ilmu-pendidikan.net, diakses pada tanggal 22 Mei 2015;

Arti new normal Indonesia : tatanan Baru beradaptasi dengan Covid-19, 2020 dalam www.https://, diakses pada hari Senin, 20 Oktober 2020.

Http://humas.narotama.ac.id. Pentingnya startegi marketing bagi perguruan Tinggi, diakses pada tanggal 20 Mei 2014;

Volume : 20, Nomor : 2

ISSN Online : 2613-9340

ISSN Offline : 1412-1255

\section{Peranan Dan Tanggung Jawab Notaris Dalam Memberikan Penyuluhan Hukum Terhadap Para Pihak Di Kota Pekanbaru}

Oleh :

\section{Brahma Putra Perkasa ${ }^{11}$}

11 Magister Kenotariatan Universitas Sumatera Utara, Medan 
Media Komunikasi dan Informasi Hukum dan Masyarakat

putrabrahma14@yahoo.com

Abstract

Abstrak

Sebagai pejabat umum, seorang Notaris dituntut untuk dapat bertanggung jawab dalam mejalankan kewenanganya agar dapat memberikan penyuluhan hukum terhadap para pihak sebelum akta itu dibuatnya. Apabila dikemudian hari akta yang telah dibuat ternyata mengandung sengketa maka hal pasti ini perlu untuk dipertanyakan, apakah kesalahan pada akta itu disebabkan oleh Notaris, ataukah para pihak yang tidak memberikan keterangan yang tidak benar diluar sepengetahuan notaris atau adakah kesepakatan yang dibuat antara Notaris dengan salah satu pihak yang menghadap, ataukah kesalahan para pihak yang tidak memberikan dokumen dengan sebenarbenarnya.

Disarankan untuk kedepannya notaris ketika melakukan penyuluhan hukum agar dapat dilakukan di hadapan para pihak dan setiap penyuluhan hukum yang telah dilakukan oleh notaris dan disetujui oleh para pihak hendaknya dituliskan dalam akta, atau jika hal tersebut tidak dapat dilakukan, notaris bisa menuangkannya dalam suatu akta tersendiri, hal ini dilakukan sebagai bukti bahwa notaris tersebut telah melakukan kewajibannya dalam memberikan penyuluhan hukum sehubungan dengan akta yang hendak dibuat.

Kata Kunci : Penyuluhan Hukum, Tanggung Jawab Notaris, Undang Undang Jabatan Notaris

\section{Pendahuluan}

\section{A. Latar Belakang}

Melihat perkembangan hukum yang ada pada masyarakat, maka akan dapat ditemukan bahwa peranan hukum dalam mengatur kehidupan masyarakat telah mengalami banyak perubahan dan perbedaan secara terusmenerus dari suatu kurun waktu ke waktu yang lain. Pada masyarakat yang lebih sederhana, hukum telah berfungsi untuk menciptakan dan juga untuk memelihara keamanan serta ketertiban. Fungsi ini juga telah berkembang sesuai dengan perkembangan yang ada pada masyarakat itu sendiri yang juga meliputi berbagai aspek dalam kehidupan di masyarakat yang memiliki sifat dinamis, memerlukan kepastian, perlindungan hukum yang berintikan kebenaran dan keadilan dan juga ketertiban. Masyarakat yang membutuhkan kepastian hukum, ketertiban, dan perlindungan hukum juga membutuhkan sektor pelayanan jasa publik yang pada saat ini juga semakin berkembang mengikuti perkembangan dan meningkatnya kebutuhan masyarakat atas pelayanan jasa. Dalam hal ini misalnya, Notaris merupakan salah satu Pelayanan Jasa Publik di bidang pembuatan akta otentik.

Ketentuan seorang Notaris dalam wewenangnya untuk membuat suatu akta otentik telah diatur dalam Undang-Undang No. 30 Tahun 2004 tentang Jabatan Notaris sebagaimana telah diubah dengan UndangUndang No. 2 Tahun 2014 UUJN. Dalam Pasal 1 angka 1 UUJN, telah disebutkan bahwa Notaris merupakan pejabat umum yang berwenang untuk membuat akta otentik dan memiliki kewenangan lainnya sebagaimana dimaksud dalam UU ini atau berdasarkan UU lainnya.

Mengenai kewenangan seorang Notaris, pasal 15 ayat (1) UUJN telah memberikan jabarannya, bahwa Notaris, dalam jabatannya, berwenang untuk membuat akta otentik mengenai semua perbuatan, perjanjian, dan penetapan yang diharuskan oleh peraturan perundang-undangan dan/atau yang dikehendaki oleh yang berkepentingan untuk dinyatakan dalam akta otentik, menjamin kepastian tanggal perbuatan akta, menyimpan 
Media Komunikasi dan Informasi Hukum dan Masyarakat

akta, memberikan grosse, salinan dan kutipan akta, semuanya itu sepanjang perbuatan akta itu tidak juga ditugaskan atau dikecualikan kepada pejabat lain atau orang lain yang ditetapkan undang-undang.

Sebagai pejabat umum, seorang Notaris dituntut untuk dapat bertanggung jawab dalam mejalankan kewenanganya agar dapat memberikan penyuluhan hukum terhadap para pihak sebelum akta itu dibuatnya. Apabila dikemudian hari akta yang telah dibuat ternyata mengandung sengketa maka hal pasti ini perlu untuk dipertanyakan, apakah kesalahan pada akta itu disebabkan oleh Notaris ataukah para pihak yang tidak memberikan keterangan yang tidak benar diluar sepengetahuan notaris atau adakah kesepakatan yang dibuat antara Notaris dengan salah satu pihak yang menghadap ataukah kesalahan para pihak yang tidak memberikan dokumen dengan sebenarbenarnya. Agar suatu akta yang telah dibuat oleh seorang Notaris tidak mengandung cacat hukum dikemudian hari, karena kesalahan notaris yang tidak memberikan penyuluhan hukum terlebih dahulu. Maka Notaris itu harus memberikan pertanggung jawaban baik secara moral maupun secara hukum. ${ }^{12}$

Penyuluhan hukum merupakan suatu bagian dari pembangunan hukum nasional, sedangkan pembangunan hukum nasional bagian dari pembangunan nasional. Kegiatan penyuluhan hukum merupakan salah satu bentuk sosialisasi untuk dapat menggambarkan bagaimana keadilan itu. Hukum nasional tidak bisa menjamin terwujudnya keadilan itu ${ }^{13}$.

12 Putri A.R, Perlindungan Hukum Terhadap Notaris Indikator Tugas-Tugas Jabatan Notaris Yang Berimplikasi Perbuatan Pidana, Sofmedia, Jakarta, 2011, hal.8.

2 Sudjito, Critical Legal Studies (CLS) dan Hukum Progresif sebagai Alternatif Dalam Reformasi Hukum
Adapun fungsi dari penyuluhan hukum itu sendiri adalah untuk suatu langkah pencegahan, langkah pemeliharaan, langkah korektif dan fungsi pengembangan. Pertama, penyuluhan sebagai langkah pencegahan (preventif), yakni untuk dapat mencegah timbulnya hak-hak yang desdruktif dan negatif yang mengakibatkan kerugian bagi masyarakat. Kedua, penyuluhan sebagai langkah pemeliharan (presevatif), yakni untuk dapat memberikan dorongan yang menciptakan partisipasi dalam suatu pembangunan hukum sesusai dengan kedudukan dan kemampuannya masingmasing. Ketiga, penyuluhan sebagai langkah korektif, yakni berfungsi sebagai upaya koreksi terhadap hal-hal yang telah ada, sehingga apabila ditemukan suatu hal yang telah melanggar hukum dapat mengurangi dampak ataupun menghilangkan hal tersebut Ke empat, penyuluhan sebagai fungsi pengembangan (developtmenta), yakni agar dapat memberi masukan dan dorongan terhadap suatu hal agar masyarakat dapat lebih mandiri dan tidak tergantung ataupun mengandalkan pihak lain. ${ }^{14}$

Dalam sektor pelayanan jasa seorang Notaris berperan sebagai pejabat yang telah diberi wewenang oleh negara untuk dapat melayani masyarakat dalam bidang perdata terkhusus dalam pembuatan akta otentik. Sebagaimana telah disebutkan dalam pasal 1 ayat (1) Undang-Undang Nomor 30 Tahun 2004 tentang Jabatan Notaris (untuk selanjutnya disebut UUJN) : " Notaris adalah pejabat umum yang berwenang untuk membuat akta otentik dan kewenangan lainnya sebagaimana dimaksud dalam undang-undang ini." Dibentuknya undang-undang Nomor 30 Tahun

Nasional dan Perubahan Kurikulum Pendidikan Hukum, Jurnal Ultimatum Sekolah Tinggi IImu Hukum Iblam, vol. 2, Edisi September, 2008, hal. 3. 
Media Komunikasi dan Informasi Hukum dan Masyarakat

2004 tentang Jabatan Notaris memiliki landasan filosofis yaitu agar terwujudnya jaminan jaminan kepastian hukum, menciptakan ketertiban dan perlindungan hukum yang berdasarkan pada kebenaran dan keadilan melalui akta yang telah dibuatnya, Notaris harus mampu memberi kepastian hukum kepada masyarakat pengguna jasa Notaris.

Notaris merupakan Pejabat Umum yang berwenang membuat akta otentik dan juga kewenangan lainnya sebagaimana yang telah dijelaskan dalam Undang-Undang Jabatan Notaris. Nomor 2 tahun 2014. Notaris adalah salah satu profesi yang juga ikut berperan aktif dalam mendukung proses penegakan hukum di dalam Negara Kesatuan Republik Indonesia. Keberadaan fungsi Notaris di Indonesia telah tergambar di dalam pasal 1868 Kitab UndangUndang Hukum Perdata yang berbunyi sebagai berikut :

"Suatu akta otentik adalah suatu akta
yang dalam bentuknya ditentukan
Undang-Undang, yang dibuat oleh atau
dihadapan pegawai-pegawai umum
yang berkuasa untuk ditempat dimana
akta dibuatnya"

Berdasarkan pada tahun 2004 diundangkanlah Undang-Undang Nomor 30 Tahun 2004 Tentang Jabatan Notaris (sebagai pengganti Staatbald 1860 nomor 30) yang kemudian telah diubah dengan Undang-Undang Republik Indonesia Nomor 2 Tahun 2014 Tentang Perubahan Atas Undang-Undang Nomor 30 tahun 2004 Tentang Jabatan Notaris. Untuk selanjutnya dalam tulisan ini disingkat dengan Undang-Undang Jabatan Notaris.

Bagi suatu akta otentik, akta tersebut mempunyai 3 (tiga) fungsi terhadap para pihak yang membuatnya berupa:
1. Sebagai bukti bahwa para pihak yang bersangkutan telah mengadakan perjanjian tertentu;

2. Sebagai bukti bagi para pihak bahwa apa saja yang telah tertulis dalam perjanjian adalah menjadi tujuan dan keinginan para pihak;

3. Sebagai bukti pada pihak ketiga bahwa pada tanggal tertentu kecuali juga ditentukan sebaliknya para pihak telah mengadakan perjanjian dan bahwa isi perjanjian adalah sesuai dengan kehendak para pihak. ${ }^{15}$

Notaris dalam menjalankan jabatan dan kewenangannya memiliki kewajiban untuk dapat bertindak amanah, jujur, tidak berpihak, mandiri, seksama dan selalu menjaga kepentingan para pihak yang terkait dalam suatu perbuatan hukum. Seorang Notaris hendaknya juga harus memiliki sifat bijaksana yang berarti harus mampu berada di tengah-tengah kedua belah pihak, memberikan penyuluhan hukum ketika para pihak sedang menghadap Notaris tanpa berpihak kepada salah satu pihak saja. Itu semua dikarenakan profesi Notaris memiliki kewajiban atas wewenang yang diberikan kepada Notaris dalam memberi penyuluhan hukum kepada para pihak yang akan membuat akta seperti yang telah di atur dalam Pasal 15 ayat (2) huruf e.

Kedudukan Notaris di Indonesia lebih sulit dari pada Notaris di negeri Belanda. Seorang Notaris menghadapi langganan (client) bermacam-macam golongan penduduk dan masing-masing mempunyai adat istiadat sendiri dan mempunyai perbedaan yang beraneka ragam. Maka dari itu seorang Notaris wajib memberikan penyuluhan hukum terlebih dahulu

15 Salim, HS, Hukum Kontrak, Teori dan Teknik Penyusunan Kontrak, Sinar Grafika, Jakarta, 2006, hal.43. 
Media Komunikasi dan Informasi Hukum dan Masyarakat

yang mudah dipahami oleh langganan pada saat berhadapan dengan notaris. ${ }^{16}$

Dalam kewajibannya memberikan penyuluhan hukum kepada para pihak peranan faktor moralitas seorang Notaris sangatlah diutamakan, hal inilah yang akan membuat seorang Notaris tidak akan menyalahgunakan wewenang yang telah ada padanya sehingga tidak akan mengakibatkan kerugian bagi para pihak dan tidak pula merugikan Notaris itu sendiri. Hingga saat ini masih banyak masyarakat yang datang menghadap kepada Notaris hanya menyerahkan begitu saja seagala sesuatunya kepada Notaris, bagaimana baiknya menurut Notaris itu sendiri, ini semua dikarenakan masih banyaknya masyarakat yang belum paham dengan permasalahan hukum.

Penyuluhan hukum dapat dilakukan dengan cara memberikan pemahaman yang benar terhadap para penghadap. Seorang Notaris harus mampu menjelaskan isi akta otentik yang telah dibuatnya karena pada kenyataannya tidak semua orang yang membuat akta otentik kepada Notaris dapat benar-benar memahami dengan baik dan benar akta tersebut. Pada keadaan ini seorang Notaris tidak akan menerima honorarium pada saat memberikan penyuluhan hukum kepada para pihak karena berdasarkan Pasal 15 ayat 2 huruf e tersebut Notaris tidak berkewajiban meminta atau memungut bayaran apapun yang terkait tentang penyuluhan hukum yang diberikan oleh Notaris kepada para pihak atau masyarakat.

\section{B. Rumusan Masalah}

Berdasarkan latar belakang yang telah diuraikan diatas, maka rumusan masalah yang dapat dikaji dalam penelitian ini adalah sebagai berikut:

1. Bagaimana peranan dan tanggung jawab notaris dalam memberikan penyuluhan hukum terhadap para pihak di kota pekanbaru?

2. Apakah yang menjadi batasan-batasan bagi seorang notaris dalam memberikan penyuluhan hukum terhadap para pihak ?

3. Bagaimanakah Akibat Hukum Jika Notaris Tidak Memberikan Penyuluhan Hukum Kepada Para Pihak?

\section{Metode Penelitian}

Pendekatan masalah yang digunakan dalam penelitian ini adalah pendekatan yuridis empiris, yaitu suatu penelitian yang mana disamping melihat aspek hukum positif juga melihat seperti apakah penerapan yang terjadi dilapangan dan masyarakat, adapun data yang diteliti awalnya adalah data sekunder yang kemudian dilanjutkan dengan penelitian terhadap data primer dilapangan, yaitu penelitian terhadap para pihak-pihak yang terkait dalam pelaksanaan tugas jabatan Notaris.

\section{Hasil dan Pembahasan}

\section{A. Peranan Dan Tanggung Jawab Notaris Dalam Memberikan Penyuluhan Hukum Terhadap Para Pihak Di Kota Pekanbaru.}

Pekerjaan Notaris adalah pekerjaan yang lebih mengutamakan pelayanan dari pada imbalan (pendapatan). Artinya mengutamakan apa yang harus dikerjakan sebagaimana kewajibannya bukan berapa bayaran yang akan

16 Arliman, Lurensius, Notaris dan Penegakkan Hukum Oleh Hakim, Budi Utama, Yogyakarta, 2015, hal. 2. 
Media Komunikasi dan Informasi Hukum dan Masyarakat

diterima, kepuasan klien adalah yang utama. ${ }^{17}$

Apabila Notaris melalaikan tanggung jawabnya dalam menjalankan tugas jabatan, ia harus dapat mempertanggungjawabkan secara moral, etis dan hukum kepada masyarakat. Tanggung jawab Notaris dalam pembuatan akta perusahaan hanya sebatas tanggung jawab terhadap akta-akta yang dibuatnya tersebut dan bukan merupakan tanggung jawab materiil Notaris yang bersangkutan.

Notaris adalah pejabat umum yang berwenang untuk membuat akta otentik dan kewenangan lainnya sebagaimana dimaksud dalam pasal 1 angka 1 Undang-Undang Nomor 2 Tahun 2014 tentang Perubahan Atas UndangUndang Nomor 30 Tahun 2004 tentang Jabatan Notaris. Menurut kamus hukum, notaris adalah orang yang mendapat kuasa dari pemerintah untuk mengesahkan dan menyaksikan berbagai surat perjanjian, surat wasiat, akta dan sebagainya. ${ }^{18}$ Gandasubrata menyatakan Notaris adalah pejabat umum yang diangkat oleh pemerintah termasuk unsur penegak hukum yang memberikan pelayanan kepada masyarakat. ${ }^{19}$ Notaris adalah Pejabat Umum yang berfungsi menjamin otoritas pada tulisan-tulisannya (akta). Notaris diangkat oleh pengurus tertinggi negara dan kepadanya diberikan kepercayaan dan pengakuan dalam memberikan jasa bagi kepentingan

\footnotetext{
${ }^{17}$ Anand, Ghansham, Karekteristik Jabatan Notaris Di Indonesia, Zifatama Publisher, Sidoarjo, 2014, hal. 118. 18 J.C.S. Simorangkir, 2013, Kamus Hukum, Aksara Baru, Jakarta, hal. 53.

19 H.R. Purwoto. S. Gandasubrata, 1998, Renungan Hukum, IKAHI Cabang Mahkamah Agung RI, Jakarta, hal. 484
}

masyarakat. ${ }^{20}$ Notaris sebagai Pejabat Umum memiliki tanggung jawab atas perbuatannya terkait dengan pekerjaannya dalam membuat akta.

Wewenang Notaris hanya dicantumkan dalam Pasal 15 ayat (1), (2), dan (3) UUJN. Menurut Pasal 15 ayat (1) bahwa wewenang Notaris adalah membuat akta otentik mengenai semua perbuatan, perjanjian dan penetapan, sepanjang pembuatan akta itu oleh suatu peraturan umum tidak juga ditugaskan atau dikecualikan kepadanya pejabat atau orang lain. ${ }^{21}$

Notaris dalam menjalankan profesinya, selain harus netral juga dituntut untuk memberikan pelayanan hukum kepada masyarakat yang memerlukan jasanya dengan sebaik-baiknya, memberikan bimbingan dan penyuluhan hukum kepada masyarakat agar masyrakat menyadari tentang hak dan kewajibannya sebagai warga Negara dan anggota masyarakat. Inilah sebabnya mengapa calon Notaris harus benar-benar menguasai seluk-beluk dan sisik-melik tentang profesi kenotariatan..$^{22}$

Pasal 1 angka 7 UUJN menjelaskan pengertian akta Notaris adalah akta otentik yang dibuat oleh atau dihadapan Notaris menurut bentuk dan tata cara yang di tetapkan dalam undang-undang ini. Berdasarkan pengertian ini dapat disimpulkan tentang penggolongan akta otentik yaitu :

1. Akta otentik yang dibuat oleh pejabat umum (akta relaas),

20 A. Kohar, 2004, Notaris Berkomunikasi, Alumni, Bandung, hal. 203.

${ }^{21}$ Habib Adjie (b), Op.cit., hal 34

22 Yuwono. Dwi, Ismantoro, Memahami Berbagai Etika Profesi Dan Pekerjaan,Tim Medpess, Yogyakarta, 2013 hal. 179 
Media Komunikasi dan Informasi Hukum dan Masyarakat

2. Akta otentik yang dibuat dihadapan pejabat umum (akta para pihak/partij akta).

Akta otentik dapat dikatakan sebagai "bukti sempurna", artinya akta otentik itu mempunyai kekuatan pembuktian sedemikian rupa karena menyatu atau melekatnya pada akta otentik itu sendiri sehingga tidak perlu dibuktikan lagi dan menurut hakim akta otentik itu merupakan bukti wajib/keharusan (verplicht bewijs). Siapa yang menyatakan akta otentik itu palsu maka ia harus membuktikannya.

Pasal 1 angka 7 UUJN menjelaskan pengertian akta Notaris adalah akta otentik yang dibuat oleh atau dihadapan Notaris menurut bentuk dan tata cara yang di tetapkan dalam undang-undang ini. Berdasarkan pengertian ini dapat disimpulkan tentang penggolongan akta otentik yaitu :

1. Akta otentik yang dibuat oleh pejabat umum (akta relaas),

2. Akta otentik yang dibuat dihadapan pejabat umum (akta para pihak/partij akta).

Akta otentik memiliki 3 kekuatan pembuktian yaitu: ${ }^{23}$

1. Kekuatan pembuktian Lahiriah, artinya akta otentik mempunyai kemampuan untuk membuktikan dirinya sendiri sebagai akta otentik, mengingat kehadirannya itu telah sesuai dan menurut ketentuan pasal 1868 KUHPerdata. Pembuktian lahiriah ini tidak ada pada akta di bawah tangan.

2. Kekuatan pembuktian Formil, bahwa apa yang dinyatakan dan dicantumkan dalam

23 Yudara, N.G. 2001. Perjanjian Kredit Bank Pemberian Jaminan Pengikatan dan Permasalahannya, Makalah disajikan dalam Seminar Perkreditan Perbankan. Bank Rakyat Indonesia. Surabaya. 12 September 2001. hal 22-23 akta otentik itu adalah benar karena merupakan uraian kehendak para pihak yang dinyatakan di dalam akta otentik itu oleh atau di hadapan pejabat yang berwenang dalam menjalankan jabatannya. Selain itu, akta otentik menjamin kebenaran tanggal, tanda tangan, komparan (orang yang menghadap) dan tempat dibuatnya akta. Dalam arti formil, akta notaris membuktikan kebenaran dari apa yang disaksikan yaitu yang dilihat, didengar dan dialami sendiri oleh Notaris sebagai pejabat umum dalam menjalankan jabatannya. Akta di bawah tangan tidak mempunyai kekuatan pembuktian formil, kecuali bila orang yang melakukan tanda tangan pada akta itu mengakui kebenaran tanda tangannya.

3. Kekuatan pembuktian Materiil, bahwa isi akta itu dianggap/dibuktikan sebagai yang benar untuk setiap orang, juga terhadap para pihak yang meminta untuk dibuatkan akta otentik itu sebagai alat bukti terhadap dirinya (termasuk ahli waris para pihak atau orang lain yang mendapat hak dari para pihak) atau dinamakan "preuve proconstituee".

B. Batasan-Batasan Bagi Seorang Notaris Dalam Memberikan Penyuluhan Hukum Terhadap Para Pihak

Ketika penghadap menghadap Notaris agar tindakan atau perbuatannya diformulasikan ke dalam akta otentik sesuai dengan kewenangan notaris, dan kemudian Notaris membuatkan akta atas permintaan atau keinginan para penghadap tersebut, maka dalam hal ini memberikan landasan kepada Notaris dan para penghadap telah terjadi hubungan hukum. Oleh karena itu Notaris harus 
Media Komunikasi dan Informasi Hukum dan Masyarakat

menjamin bahwa akta yang dibuat tersebut telah sesuai menurut hukum yang sudah ditentukan, sehingga kepentingan yang bersangkutan terlindungi dengan akta tersebut. $^{24}$

Pada dasarnya bahwa hubungan antara Notaris dan para penghadap yang telah membuat akta di hadapan atau oleh Notaris tidak dapat dikonstruksikan, ditentukan pada awal Notaris dan para penghadap berhubungan, karena pada saat itu belum terjadi permasalahan apapun. Untuk menentukan bentuk hubungan antara Notaris dengan para penghadap harus dikaitkan dengan ketentuan Pasal 1869 KUHPerdata, bahwa akta otentik terdegradasi menjadi mempunyai kekuatan pembuktian sebagai akta dibawah tangan dengan alasan : (1)Tidak berwenangnya pejabat umum yang bersangkutan, atau (2)Tidak mampunya pejabat umum yang bersangkutan, atau (3) Cacat dalam bentuknya, atau karena akta Notaris dibatalkan berdasarkan keputusan pengadilan yang telah mempunyai kekuatan hukum, maka hal ini dapat dijadikan dasar untuk menggugat Notaris sebagai suatu perbuatan melawan hukum atau dengan kata lain hubungan Notaris dan para penghadap dapat dikualifikasikan sebagai perbuatan melawan hukum, karena: ${ }^{25}$

1. Notaris tidak berwenang membuat akta yang bersangkutan,

2. Tidak mampunya Notaris yang bersangkutan dalam membuat akta,

3. Akta Notaris cacat dalam bentuknya.

Dengan adanya penyuluhan hukum yang diberikan oleh notaris, diharapkan para

\footnotetext{
${ }^{24}$ Habib Adjie (b), Loc.cit., hal. 17.

25 lbid.
}

penghadap yang memerlukan bantuannya menjadi paham dan mengerti mengenai keputusan yang terbaik yang akan diperbuatnya dan juga sebelum notaris membuatkan akta yang diinginkan oleh kliennya, notaris harus terlebih dahulu memberikan suatu penjelasan mengenai keadaan hukum yang sebenarnya kepada klien, hak dan kewajiban mereka masing-masing, agar klien tersebut mengerti akan keadaan yang sebenarnya.

Penyuluhan hukum adalah kegiatan
dengan tujuan utamanya agar
masyarakat tau hukum, paham hukum,
sadar hukum, untuk kemudian patuh
pada hukum tanpa paksaan, tapi
menjadikannya sebagai suatu
kebutuhan. Dalam tulisannya Prof. Dr.
Satjipto Rahardjo mengatakan:

"Hukum tidak perlu mengatur masyarakat secara penuh, total (full regulation) cukup sekedar membuat skema besar, sedang proses-proses nyatanya diserahkan kepada masyarakat. Tanpa mengganggu kelangsungan hidup yang sudah berjalan."26

Pada penyuluhan akan selalu diusahakan tumbuhnya kesadaran hukum pada diri seseorang sehingga ia akan menjadi faham, tahu, mengerti dan dapat melaksanakan dengan iklas kaidah-kaidah hukum yang telah berlaku. Penyuluhan hukum bagi notaris sendiri telah dijelaskan pada Pasal 15 ayat (2) huruf e bahwa notaris berkewajiban untuk memberikan penyuluhan hukum kepada para penghadap yang ingin membuat akta kepadanya. Ketentuan ini sesungguhnya bertujuan agar penyuluhan

\footnotetext{
Rahardjo Satjipto, Hukum Dalam Jagat Ketertiban, (Jakarta: Penerbit UKI Pree, 2006), hal. 55.
} 
Media Komunikasi dan Informasi Hukum dan Masyarakat

hukum yang dilakukan oleh notaris dapat memberikan kesadaran dan pengetahuan akan hak dan kewajiban para penghadap sebagai warga negara dan anggota masyarakat.

Para pihak adalah orang yang satu dengan orang yang lainnya mengadakan suatu perbuatan hukum dihadapan seorang notaris. Seorang notaris memiliki tugas untuk dapat mengkonstantir hubungan hukum antara para pihak dalam bentuk tertulis dan format tertentu, sehingga menjadi suatu akta otentik. Para pihak datang ke notaris agar tindakan atau perbuatan hukumnya diformulasikan ke dalam akta otentik sesuai dengan kewenangan notaris, kemudian notaris membuatkan akta atas permintaan atau keinginan para pihak tersebut, maka dalam hal ini memberikan landasan kepada notaris dan para pihak telah terjadi hubungan hukum. Notaris harus menjamin bahwa akta yang dibuat tersebut telah sesuai menurut aturan hukum yang sudah ditentukan, sehingga kepentingan yang bersangkutan terlindungi dengan akta tersebut. ${ }^{27}$

Untuk itu dalam praktek sehari-hari notaris diwajibkan untuk senantiasa menjunjung tinggi hukum dan asas negara serta bertindak sesuai dengan makna sumpah jabatan dan mengutamakan pengabdiannya kepada kepentingan masyarakat dan negara. Adanya kewajiban kepribadian yang baik dan tuntutan untuk menjunjung tinggi martabat jabatan notaris, dengan demikian dalam pelaksanaan jabatannya notaris tidak dibenarkan melakukan hal-hal dan/atau tindakan yang tidak sesuai dengan martabat dan kehormatan jabatan notaris.

\section{Akibat Hukum Jika Notaris Tidak Memberikan Penyuluhan Hukum Kepada Para Pihak}

27 Habib Adjie, Hukum Notaris Indonesia (Tafsir Tematik Terhadap UU No.30 Tahun 2004 Tentang Jabatan Notaris), cet.2, Refika Aditama, Bandung, 2009, hal. 15-16.
Pelaksanaan penyuluhan hukum tersebut tidak diatur secara khusus, tetapi notaris juga tetap mempunyai tanggung jawabnya yaitu tanggung jawab secara moral terhadap jabatan yang diembannya. Karena notaris merupakan pejabat yang dipercaya dan dalam melaksanakan tugasnya selalu dijiwai Pancasila, sadar dan taat kepada hukum Jabatan Notaris, sumpah jabatan dan juga Kode etik notaris. ${ }^{28}$

Jika penghadap merasakan ada suatu ketidakpuasan atas penjelasan yang diberikan oleh notaris tersebut maka secara hukum disahkan bahwa penghadap yang bersangkutan boleh menanyakan kepada notaris lainnya. Terhadap penjelasan hukum yang diberikan notaris, para penghadap bebas untuk menentukan keputusan yang akan diambilnya.

Dengan demikian penjelasan tersebut dapat diikuti oleh para penghadap atau tidak ditulis di dalam akta. Bedasarkan alasan tersebut maka jika ada kesalahan didalam akta sehingga menimbulkan kerugian bagi para pihak bukan kesalahan notaris maka notaris tersebut tidak dapat dituntut tanggung jawabnya karena apa yang tercantum di dalam akta merupakan keinginan dari para pihak sendiri sementara notaris hanya menuangkannya saja dari kehendak para pihak didalam akta otentik, sehingga konsekuensinya ditanggung oleh penghadap sendiri. Akan tetapi jika notaris tersebut memberikan suatu penyuluhan hukum yang diikuti dengan pembuatan akta, ternyata menimbulkan suatu kerugian bagi kliennya karena kesalahan dari notaris sendiri maka notaris tersebut dapat dituntut tanggung jawabnya. Sebaliknya jika kerugian yang

28 Santoso, Agus, Hukum Moral Dan Keadilan, Kencana, Jakarta, 2012, hal. 114. 
Media Komunikasi dan Informasi Hukum dan Masyarakat

ditimbulkan bukan karena kesalaha notaris maka notaris tidak dapat dituntut tanggung jawabnya.

Dalam PJN maupun UUJN dan Kode Etik Jabatan Notaris, tidak ada pengaturan secara spesifik adanya sanksi pidana terhadap Notaris. Dalam praktik ditemukan kenyataan bahwa suatu tindakan hukum atau pelanggaran yang dilakukan Notaris sebenarnya dapat dijatuhi sanksi Administrasi atau Perdata atau Kode Etik Jabatan Notaris, tapi kemudian ditarik atau dikualifikasikan sebagai suatu tindak pidana yang dilakukan oleh Notaris.

Penjatuhan hukuman pidana terhadap Notaris tidak serta merta akta yang bersangkutan menjadi batal demi hukum. Suatu hal yang tidak tepat secara hukum jika ada putusan Pengadilan Pidana dengan amar putusan membatalkan akta Notaris dengan alasan Notaris terbukti melakukan suatu tindakan pidana pemalsuan. Dengan demikian yang harus dilakukan oleh mereka yang akan atau berkeinginan untuk menempatkan Notaris sebagai terpidana, atas akta yang dibuat oleh atau dihadapan Notaris yang bersangkutan, maka tindakan hukum yang harus dilakukan adalah membatalkan akta yang bersangkutan memalui gugatan. ${ }^{29}$

Dengan demikian sebelum akta ditandatangani, notaris diwajibkan untuk terlebih dahulu membacakan apa yang tertuang dan tertulis didalam akta sesuai dengan apa yang dikehendaki oleh klien maka setelah aktanya dibuat oleh notaris yang bersangkutan ternyata menimbulkan kerugian bagi salah satu pihak maka notaris yang bersangkutan tidak dapat dituntut tanggung jawabnya. Dengan alasan

29 Arliman, Laurensius, Notaris Dan Penegakkan Hukum Oleh Hakim, Deepublish, Yogyakarta, 2015, hal. 52. bahwa jika akta telah ada, maka yang berbicara bukan para pihak lagi melainkan akta tersebut karena apa yang tertulis di dalam akta sebagai alat bukti yang otentik.

\section{Penutup}

\section{A. Kesimpulan}

1. Peran dan tanggung jawab Notaris dalam memberikan penyuluhan hukum terhadap para pihak telah diwajibkan kepada setiap Notaris. Dalam memberikan penyuluhan hukum, Notaris berperan untuk selalu bertindak jujujur dan tidak berpihak, memberikan pelayanan sesuai dengan ketentuan yang berlaku didalam undangundang, serta merahasiakan segala keterangan dan segala sesuatu yang diperolehnya dari para penghadap atau kliennya kepada pihak lain. Batasanbatasan bagi seorang notaris dalam memberikan penyuluhan hukum kepada kliennya, notaris harus memberikan penjelasan mengenai keadaan hukum yang sebenarnya sesuai dengan peraturan perundang-undangan yang berlaku, menjelaskan hak dan kewajiban para pihak agar tercapai kesadaran hukum yang tinggi dalam masyarakat, bertindak jujur, tidak berpihak dan dengan penuh rasa tanggung jawab mentaati kentuan didalam UUJN, kode etik notaris dan sumpah jabatan.

2. Akibat hukum apabila notaris tidak memberikan penyuluhan hukum kepada para pihak yang menimbulkan kerugian bagi para pihak dikemudian hari, maka apabila kerugian tersebut timbul karena kesalahan dari notaris itu sendiri maka notaris itu dapat dituntut tanggung jawabnya. Sebaliknya, jika kerugian yang timbul bukan karena 
Media Komunikasi dan Informasi Hukum dan Masyarakat

kesalahan notaris maka notaris tidak dapat dituntut tanggung jawabnya.

3. Akibat hukum apabila notaris tidak memberikan penyuluhan hukum kepada para pihak yang menimbulkan kerugian bagi para pihak dikemudian hari, maka apabila kerugian tersebut timbul karena kesalahan dari notaris itu sendiri maka notaris itu dapat dituntut tanggung jawabnya. Sebaliknya, jika kerugian yang timbul bukan karena kesalahan notaris maka notaris tidak dapat dituntut tanggung jawabnya.

\section{DAFTAR PUSTAKA}

\section{A. Buku}

Abdul Ghofur Anshori, Lembaga Kenotariatan Indonesia, Yogyakarta, UII Press, 2009.

Amirudin El Zaini Asikin, Pengantar Metode Penelitian Hukum, Rajawali Pers, Jakarta, 2003.

Aridwan Halim, Pengantar IImu Hukum dalam Tanya Jawab, Ghimia Indonesia, Bogor, 2005.

Departemen Pendidikan dan kebudayaan, kamus Besar Bahasa Indonesia, Balai Pustaka, Jakarta, 1989.

G.H.S Lumban Tobing, Peraturan Jabatan Notaris, Erlangga, Jakarta, 1999.

Habib Adjie, Sanksi Perdata dan Administratif Terhadap Notaris Sebagai Pejabat Publik, Refika Aditama, Bandung, 2009.

Hans Kelsen, Teori Hukum Murni Dengan Judul Buku Asli General Theory of Law and State, Rumidi Pers, Jakarta.

Hans Kelsen, Teori Hukum Murni, diterjemahkan oleh Raisul Mutaqien, Nuansa \& Nusamedia, Bandung, 2006.

Herlien Budiono, Kumpulan Tulisan Hukum Perdata di Bidang Kenotariatan, Buku
Kedua, PT. Citra Aditya Bakti, Bandung, 2010.

Hery Susanto, Peranan Notaris Dalam Menciptakan Kepastian Dalam Kontrak, FH UI Press, Yogyakarta, 2010.

Koesnadi Hardjasoemantri, Hukum Tata Lingkungan, Gajah Mada University Press, Yogyakarta, 1988.

Komar Andasasmita, Notaris I, Penerbit Sumur, Bandung, 1981.

Maritman Prodjohamidjojo, Penyelidikan dan Penyidikan, Ganesa Indonesia, Jakarta, 1985.

Muhammad Abdulkhadir, Etika Profesi Hukum, Citra Aditya Bakti, Jakarta, 2006.

Munir Fuady, Hukum Kontrak Dari Sudut Pandang Hukum Bisnis, Citra Aditya Bakti, Bandung, 1999.

Munir Fuady, Perbuatan Melawan Hukum Pendekatan Kontemporer, PT. Citra Aditya Bakti, Bandung, 2002.

Peter Mahmud Marzuki, Pengantar IImu Hukum, Cetakan Kedua, Kencana Prenada Media Group, Jakarta, 2009.

Putri A.R, Perlindungan Hukum Terhadap Notaris ( Indikator Tugas-Tugas Jabatan Notaris yang Berimplikasi Perbuatan Pidana), Sofmedia, Jakarta, 2011.

R. Soegondo Notosidoerjo, Hukum Notariat di Indonesia-Suatu Penjelasan, Raja Grafindo Persada, Cetakan Kedua, Jakarta, 1993.

Ridwan HR, Hukum Administrasi Negara, PT. Raja grafindo Persada, Jakarta, 2010.

Roemasiti Prayitno, Tugas dan Tanggung Jawab Notaris Sebagai Pejabat Pembuat Akta, Media Notariat, No. 1213/Tahun IV, Okteber 1989.

Sadijono, Memahami Beberapa Bab Pokok Hukum Administrasi, Laks Bang Pressindo, Yogyakarta, 2008.

Salim HS, Hukum Kontrrak, Teori dan Tekhnik Penyusunan Kontrak, Sinar Grafika, Jakarta 2006. 
Media Komunikasi dan Informasi Hukum dan Masyarakat

Salim HS, Perkembangan Teori Dalam IImu Hukum, Rajawali Pers, Jakarta, 2010.

Salim, HS, dan Erlies Septinana Nurbaini, penerapan Teori Hukum Pada Penelitian Disertasi dan Tesis, Buku Ke Dua, Rajawali, Pres, Jakarta.

Salim, HS, Hukum Kontrak, Teori dan Teknik Penyusunan Kontrak, Sinar Grafika, Jakarta, 2006.

Salim, HS, Hukum Kontrak, Teori dan Teknik Penyusunan Kontrak, Sinar Grafika, Jakarta, 2006.

Satjipto Raharjo, IImu Hukum, Alumni, Bandung, 2000.

Soerjono Soekanto, Beberapa Cara dan Mekanisme dalam Penyuluhan Hukum, Jakarta: Pradnya Paramita, 1986.

Soerjono Soekanto, Faktor-faktor Yang Mempengaruhi Penegakan Hukum, Raja, Grafindo Perkasa, Jakarta, 2012.

Soetardjio Soematmodjo, Apakah: Notaris, PPAT, Pejabat Lelang, Libertu, Yogyakarta, 1986.

Subekti, Pokok-Pokok Hukum Perdata, Intermasa, Jakarta, 1987.

Sudikno Mertokusumo, Hukum Acara Perdata Indonesia, Cetakan Pertama, Liberty, Yogyakarta, 2006.

Tan Thong Kie, Studi Notaris, Serba-Serbi Praktek Notaris, Ichtiar Baru Van Hoeve, Jakarta, 1994.

Victor Martin Cori, Kewajiban Notaris Yang Telah Di Angkat dan Disumpah Untuk Menjalankan Jabatan di Kota Padang, Tesis, Program Studi Magister Kenotariatan Program Pasca Sarjana Universitas Diponegoro Andalas Padang, Tahun 2017.

Victor Simatupang dan Cormentyna Sitanggang, Grossse Akta Dalam Pembuktian dan Eksekutorial, cet.1, Rineka Cipta, Jakarta, 1993.

Wawan Muhran Hariri, Pengantar IImu Hukum, Pustaka Setia, Bandung, 2012.

\section{B. Peraturan Perundang-Undangan}

Undang-Undang Dasar Negara Republik Indonesia Tahun 1945

Undang-Undang Tentang Jabatan Notari Undang-Undang Nomor 30 Tahun 2004 LN. No. 117 Tahun 2004 TLN. No. 4432 .

Undang-Undang tentang Perubahan Atas Undang-Undangang Nomor 30 Tahun 2004 tentang Jabatan Notaris, UndangUndang Nomor 2 Tahun 2014 LN. No. 3 Tahun 20014 TLN. No. 5491.

\section{Jurnal}

Rahmad Hendra. 2012. Tanggung Jawab Notaris Terhadap Akta Otentik Yang Penghadapnya Menggunakan Identitas Palsu Di Kota Pekanbaru. Jurnal IImu Hukum. 3 (01). (Februari, 2012).

Faisal A. Rani. 2019. Kedudukan Notaris Sebagai Pejabat Umum Ditinjau Dari Konsep Equality Before The law. Jurnal Hukum dan Pembangunan. 49 (01). (Februari, 2019).

Sholikhkah Entin. 2017. Perlindungan Hukum TerhadapNotaris Yang Diduga Melakukan Malpraktek Dalam Proses Pembuatan Akta Otentik. Jurnal Akta. 4 (01). (Maret, 2017).

Ma'ruf Umar. 2015. Tinjauan Hukum Kedudukan Dan Fungsi Notaris Sebagai Pejabat Umum Dalam Membuat Akta Otentik. Jurnal Pembaharua Hukum. 2 (3). (September-Desember, 2015).

\section{Internet}

Hukum Pedia, Perbedaan Antara Teori Hukum Positivisme John Austine Dengan Teori Hukum Progresif Satjipto Rahardjo, Hukum Pedia, http://www.hukumpedia.com/lkmp unha s/perbedaan-antara-teori-hukumpositivisme-john-austine-dengan-teorihuku-progresif-satjipto-rahardjo, terakhir diakses pada 20 Desember 2017.

Mowoka V.P, Pelaksanaan Tanggung Jawab Notaris terhadap Akta yang Dibuatnya. Lex Et Societatis, Lex Et Sociatis, https://ejournal.unsrat.ac.id/index.php/le xetsocietatis/article/view/4671, terakhir diakses pada 14 Juli 2014. 
